Geosistemy perehodnykh zon = Geosystems of Transition Zones / Геосистемы переходных зон

Content is available under the Creative Commons Attribution 4.0 International License (CC BY 4.0)

2020, vol. 4, No. 4, pp. 500-505

URL: http://journal.imgg.ru/archive.htm ; https://elibrary.ru/title about.asp?id=64191

https://doi.org/10.30730/gtrz.2020.4.4.500-505

SHORT REPORT

\title{
Activation of the Ebeko volcano in May-July, 2020 \\ (Paramushir Island, Northern Kuril Islands)
}

Artem V. Degterev*, Marina V. Chibisova

Institute of Marine Geology and Geophysics, FEB RAS, Yuzhno-Sakhalinsk, Russia

*E-mail: d_a88@mail.ru

\section{Abstract PDF ENG Резюме $\underline{\text { PDF RUS } \quad \text { Full text PDF RUS }}$}

Abstract. The Ebeko volcano located in the northern part of Paramushir Island (Northern Kuril Islands), is currently the most active volcano of the Kuril Island arc: since 2016, next explosive eruption has continued, proceeding in the form of regular ash-gas explosions of moderate force. In the period from January 2018 to October of 2020 a total of at least 1834 emissions were recorded (during daylight hours and under good weather conditions). In MayJuly 2020, the intensification of the eruptive activity of the volcano was observed, that manifested in a sharp increase of the emissions frequency and height. During this period, 296 emissions were recorded, 90 of which were at an altitude of $3 \mathrm{~km}$ or more.

\section{Keywords:}

\section{Kuril Islands, the Ebeko volcano, ash, eruption, volcanic activity monitoring}

For citation: Degterev A.V., Chibisova M.V. Activation of the Ebeko volcano in May-July, 2020 (Paramushir Island, Northern Kuril Islands). Geosistemy perehodnykh zon = Geosystems of Transition Zones, 2020, vol. 4, no. 4, pp. 500-505. (In Russ., abstr. in Engl.). https://doi.org/10.30730/gtrz.2020.4.4.500-505

Для цитирования: Дегтерев А.В., Чибисова М.В. Активизация вулкана Эбеко в мае-июле 2020 г. (о. Парамушир, Северные Курилы). Геосистемы переходных зон, 2020, т. 4, № 4, с. 500-505. https://doi.org/10.30730/gtrz.2020.4.4.500$\underline{505}$

\section{References}

1. Gorshkov G.S. 1967. Vulkanyzm Kuril'skoy ostrovnoy dugi [Volcanism of the Kuril island arc]. Moscow: Nauka, 287 p. (In Russ.).

2. Degterev A.V., Chibisova M.V. 2020. The volcanic activity at the Kuril Islands in 2019. Geosistemy perehodnykh zon = Geosystems of Transition Zones, 4(1): 93-102. (In Russ.). https://doi.org/10.30730/2541-8912.2020.4.1.093-102

3. Kotenko T.A., Kotenko L.V., Sandimirova E.I., Shapar' V.N., Timofeeva I.F. 2010. Eruption of Ebeko volcano from January through June 2009 (Paramushir Island, the Kuriles). Vestnik KRAUNTs. Nauki o Zemle = Bull. of KRAESC. Earth Sciences, 1(15): 56-68. (In Russ.).

4. Kotenko T.A., Kotenko L.V., Sandimirova E.I., Shapar' V.N., Timofeeva I.F. 2012. Eruption activity of Ebeko volcano (Paramushir I.) in 2010-2011. Vestnik KRAUNTs. Nauki o Zemle = Bull. of KRAESC. Earth Sciences, 1(19): $160-167$. (In Russ.).

5. Kotenko T.A., Kotenko L.V., Shapar' V.N. 2007. Increased activity on Ebeko volcano, Paramushir I., North Kuriles in 20052006. J. of Volcanology and Seismology, 1(5): 285-295. https://doi.org/10.1134/s0742046307050016

6. Kotenko T.A., Sandimirova E.I., Kotenko L.V. 2018. The 2016-2017 eruptions of Ebeko volcano (Kuriles Islands). Vestnik KRAUNTs. Nauki o Zemle = Bull. of KRAESC. Earth Sciences, 1(37): 32-42. (In Russ.).

7. Menyaylov I.A., Nikitina L.P., Budnikov V.A. 1992. [The Ebeco volcano activity in 1987-1991: character of eruptions, eruptive products features, hazard for Severo-Kurilsk town]. Vulkanologiya $i$ seysmologiya = Volcanology and Seismology, 5-6: 21-33. (In Russ.).

8. Rybin A.V., Chibisova M.V., Degterev A.V. Monitoring of volcanic activity in the Kurile Islands: 15 years of work SVERT group. Geosistemy perehodnykh zon = Geosystems of Transition Zones, 2(3): 259-266. (In Russ.). doi.org/10.30730/25418912.2018.2.3.259-266

9. Rychagov S.N., Belousov V.I., Glavatskikh S.F. 2002. [North Paramushir hydrothermal -magmatic system: the characteristics of deep geological section and model of modern mineral and ore formation in its interior]. Volcanology and Seismology, 4: 3-21. (In Russ.).

10. Fedorchenko V.I., Abdurakhmanov A.I., Rodionova R.I. 1989. [Volcanism of the Kuril island arc: geology and petrogenesis]. Moscow: Nauka, 237 p. (In Russ.).

11. Firstov P.P., Akbashev R.R., Makarov E.O., Kotenko T.A., Budilov D.I., Lobacheva M.A. 2020a. Geophysical observations of the Ebeko volcano's eruption (Paramushir Island, Russia) over the period September 2018 - April 2019. Vestnik KRAUNTs.

Nauki o Zemle = Bull. of KRAESC. Earth Sciences, 1(45): 89-99. (In Russ.). doi:10.31431/1816-5524-2019-3-43-89-99 
12. Firstov P.P., Kotenko T.A., Akbashev R.R. 2020b. Growth of explosive activity of Ebeko volcano in April-June 2020. Vestnik KRAUNTs. Nauki o Zemle = Bull. of KRAESC. Earth Sciences, 2(46): 10-15. (In Russ.). https://doi.org/10.31431/1816-55242020-2-46-10-15

13. Chibisova M.V., Degterev A.V. The activity of the Kurile volcanoes in 2018. Vestnik KRAUNTs. Nauki o Zemle = Bull. of KRAESC. Earth Sciences, 1(41): 91-98. (In Russ.). doi:10.31431/1816-5524-2019-1-41-91-98

14. Walter T.R., Belousov A., Belousova M., Kotenko T., Auer A. 2020. The 2019 eruption dynamics and morphology at Ebeko volcano monitored by Unoccupied Aircraft Systems (UAS) and field stations. Remote Sensing, 12(12): 1961. https://doi.org/10.3390/rs12121961 